\title{
Migration, Remittances, Trade Openness and Economic Growth in Africa: GMM Technique \\ Abdelbagi $\mathrm{E}^{*}$ \\ Department of Economics, Universiti Putra Malaysia, Selangor, Malaysia
}

\begin{abstract}
This study investigates the impact of outgoing migration, remittances, and trade on economic growth in Africa during the period from 1976 to 2015. The study utilizes annual data obtained from the World Bank and uses GMM econometrics technique. The empirical results reveal that outgoing migration has negative significant impact on economic growth of the region; migrants' remittances to Africa have positive significant impact on economic growth during period of interest. Also, the results suggest that trade contributes positively and significantly to economic growth in the continent.
\end{abstract}

Keywords: Migration; Remittances; Trade; Africa; GMM

\section{Introduction}

Immigration spurs economic growth of receiving country in two ways. First, it expands workforce and encourages more business startups. Second, it increases economic efficiency by supplying more labor to low- and high-skill labor markets. Also, high-skill migrants helps in transferring the advance technology which reflects reduction in production cost and lowers the cost associated with trade and increases economic growth [1]. However, Africa suffers from a huge outgoing migration due to a many problems that facing Africans such as political instability, lack of health care and poverty $[2,3]$. As a result, large number of African outgoing migrants causes loss of human capital in the continent.

A key challenge for African States who already face serious human resource shortages is skills migration or 'brain drain'. The African human resource pool is continuously depleted as the educated choose to emigrate and apply their skills abroad [4]. In the case of the health sector, where African countries are facing increasing demand as a result of HIV/AIDS and other diseases, several countries experience a net depletion of their health work force [5-7]. For example, 926 Ghanaian doctors practice in the OECD alone, representing a much-needed 29 percent of the doctors still practicing in Ghana [1].

On other hand, African migrants contribute to the development of their countries through many channels. For instance, inflows of migrants' remittances to Africa create income multipliers of receiving households that becoming critical resources for local development [1]. Also, those migrants' remittances create more financial sources for other sectors in the receiving countries such as investment and trade and human development [8]. Therefore, this study aims to examine the impact of outgoing migration, migrants' remittances on economic growth in Africa during the period 1976 till 2015. The rest of the paper organized as follow: Section 2 is literature review, section 3 is data, empirical model and econometrics technique, section 4 is results and discussion and section 5 is conclusion.

\section{Literature Review}

Migration boosts the working-age population; also migrants arrive with skills and contribute to human capital development of receiving countries, plus that, migrants also contribute to technological progress [3]. On the other hand, outgoing migration limits economic activities due to the loss in human capital and high-skill labor force in the country since development needs educated and trained labor to take place [9]. Christiaensen et al., [10] argue that migration causes more economic growth, helps in reducing poverty in the poorer areas and increases standards of living of the migrants' families.

Importantly, migration helps in the issue of business start-ups and facilitates trade in the receiving countries. Trade as a percentage of GDP increases economic growth and also reduces poverty [6], also it attracts more FDI inflows to Africa [6]. Furthermore, trade contributes positively to other sectors in the economy such as agriculture, industry and services; this will not only grow the economy but also build-ups foreign reserves and heighten the economic growth of the country [11].

Empirical works concluded that remittances reduce instability of households' consumption, it also boost economic growth and financial development [12-14]. In addition, remittances increase total investment in country by providing informal source of finance for families and households after fulfilling consumption and other needs [15]. Besides, remittances build-ups human capital since migrants' families invest more in health care and educating their children, such investments accumulate human capital and promote economic growth $[16,17]$.

Most importantly, inflows remittances to Africa increased dramatically over the past years, this will not only heighten economic growth and other development activities, but also will help in the issue of poverty reduction in the continent $[18,19]$. From this end, migrants' remittances to Africa will create more economic growth and help in other development sectors and activities, while remittances reduce poverty in the receiving countries households tend to invest more in educating themselves and build-up more human capital stock.

\section{Methodology, Empirical Model and Data}

This study uses the Generalized Method of Moments (GMM) to estimate the impact of outgoing migration, remittances, and trade openness on economic growth. In econometrics, the generalized method of moments (GMM) is a generic method for estimating parameters in statistical models. Usually we apply (GMM) for semi-parametric

*Corresponding author: Abdelbagi E, Department of Economics, Universiti Putra Malaysia, Selangor, Malaysia, Tel: +60109604001; E-mail: a.abdelbagi@hotmail.com

Received May 18, 2016; Accepted June 06, 2016; Published June 10, 2016

Citation: Abdelbagi E (2016) Migration, Remittances, Trade Openness and Economic Growth in Africa: GMM Technique. J Glob Econ 4: 194 doi:10.4172/2375-4389.1000193

Copyright: () 2016 Abdelbagi E. This is an open-access article distributed under the terms of the Creative Commons Attribution License, which permits unrestricted use, distribution, and reproduction in any medium, provided the original author and source are credited. 
models, where the coefficients of interest is finite-dimensional. Besides, the full shape of the data's distribution function may not be known, and therefore the maximum likelihood estimation is not applicable. The method requires that a certain number of moment conditions were specified for the model. These moment conditions are functions of the model parameters and the data, such that their expectation is zero at the true values of the parameters. The GMM method then minimizes a certain norm of the sample averages of the moment conditions.

The GMM estimators are known to be consistent, asymptotically normal, and efficient in the class of all estimators that do not use any extra information aside from that contained in the moment conditions. One of the GMM's features is the moment conditions increase with the time. Thus, the Sargan test performed to test the over-identification restrictions. There is convincing evidence that too many moment conditions introduce bias while increasing efficiency. Therefore, it suggested that a subset of these moment conditions should be used to take advantage of the trade-off between the reduction in bias and the loss in efficiency. Baltagi et al., [20] and the references cited there. Most importantly, GMM also eliminates any endogeneity that may be due to the correlation of these country specific effects and the right hand side regressors. The moment conditions utilize the orthogonally conditions between the differenced errors and lagged values of the dependent variable.

\section{Data and Empirical Model}

\section{Generalized method of moments}

This study used Generalized Method of Moments (GMM) technique in order to estimate the impact of outgoing migration and inflow remittances on economic growth in Africa during the period of interest.

\section{Empirical model}

To estimate the impact of outgoing migration, remittances, and trade openness on economic growth in Africa, the study uses the following formula:

$$
\ln Y_{i t}=\text { в }+O_{0}^{\prime} \ln Y_{i t-1}+O_{1}^{\prime} \ln M R_{i t}+O_{2}^{\prime} \ln R E_{i t}+O_{3}^{\prime} \ln T R_{i t}+\mu_{i t}
$$

Where $Y$ is the proxy of economic growth, $Y_{\mathrm{t}-1}$ is the lagged dependent variable, $M R$ is outgoing migration, $R E$ is remittances, $T R$ is trade openness, and $\mu$ is the error term; $i$ refers to the country $(\mathrm{i}=1, \ldots$ .., $\mathrm{N})$ and $t$ refers to the time period $(\mathrm{t}=1, \ldots, \mathrm{t}) .6, \mathrm{O}_{0,}^{\prime} \mathrm{O}_{1}^{\prime}, \mathrm{O}_{2}^{\prime}$ and $\mathrm{O}_{3}^{\prime}$ are the slope parameters to be estimated which are expected to be positive.

Equation (1) demonstrates that economic growth in Africa is a function of past value of economic growth $\left(Y_{t-1}\right)$, outgoing migration $(M R)$, remittances $(R E)$, trade openness (TR). To estimate Equation (1) the study uses the generalized method of moments (GMM).

\section{Data}

This study utilized annual data from World Bank. The study covers the period from 1975 to 2014 . The used GDP per capita to proxy economic growth, trade as a percentage of GDP to proxy trade, total outgoing migrants to proxy migration, and total inflows remittances to proxy remittances in Africa (Table 1).

\section{Econometrics Results}

Table 2 reports the descriptive statistics of the variables that used in this study, which are economic growth, trade openness, outgoing migration, and remittances.
Table 3 reports the results of the GMM dynamic estimation that conducted to estimate the impact of remittances, trade and outgoing migration on economic growth in Africa.

The results reveal that economic growth depends on the past value of economic growth in Africa. Also, outgoing migration is negatively contributes to economic growth during period of interest. On other hand, remittances and trade have positive significant impact on economic growth of African countries. In general, Africa suffers from huge number of outgoing migrants which cause loss in human capital stock in the continent. For instance, educated and trained labors prefer to supply their skills abroad to get high salary instead of what they will get if they worked in their countries [17]. This justifies the negative impact of outgoing migration on economic growth due to the shortage in skilled and trained labors which harm the economic activities and lower economic development in Africa.

However, those migrants contribute positively to economic growth in Africa through their remittances to the continent. Migrants' remittances help receiving families to cover their life's needs such as food and clothes, and therefore they tend to invest the rest in health care and education of their children. This will not only improve the life style of the receivers but also helps in building-ups human capital stock in these receiving countries by increasing the number of educated labors and healthier workers. In addition, trade significantly grows the economy in Africa as it attracts more FDI flows to Africa [6]. According to the World Bank (2016) African economy depends mostly on trade and goods and services, this reflects the positive significant impact that running from trade to economic growth in the region.

\section{Conclusion}

This study investigated the impact of outgoing migration, remittances, and trade on economic growth in Africa during the period

\begin{tabular}{|c|c|c|c|}
\hline Variable & Description & Measurement & Source \\
\hline$Y$ & GDP per capita & $\$$ & WDI, World Bank \\
\hline$M R$ & Migration & Total migrants & WDI, World Bank \\
\hline$R E$ & Remittances & \$ Billion & WDI, World Bank \\
\hline$T R$ & Trade Openness & $\%$ of GDP & World Bank \\
\hline
\end{tabular}

Table 1: Shows the description of the data that utilized in this study.

\begin{tabular}{|c|c|c|c|c|c|}
\hline Variable & Mean & Std. Dev. & Min & Max & Observations \\
\hline$Y$ & 2212 & 377 & 442 & 37965 & $\mathrm{~N}=1999, \mathrm{n}=50, \mathrm{~T}=40$ \\
\hline$R E$ & 332 & 221 & 221 & 432 & $\mathrm{~N}=2000, \mathrm{n}=5, \mathrm{~T}=40$ \\
\hline$T R$ & 74 & 42 & 6 & 566 & $\mathrm{~N}=2000, \mathrm{n}=50, \mathrm{~T}=40$ \\
\hline$M R$ & 554 & 112 & 323 & 765 & $\mathrm{~N}=1994, \mathrm{n}=50, \mathrm{~T}=40$ \\
\hline
\end{tabular}

Note: RE is in $\$$ billion

Table 2: The descriptive statistics of the variables.

\begin{tabular}{|c|c|}
\hline Variable & Coefficient \\
\hline$Y_{\hbar-1}$ & $0.7543^{* *}(0.321)$ \\
\hline $\operatorname{In} M R$ & $-0.013^{*}(0.002)$ \\
\hline $\operatorname{InRE}$ & $0.112^{* * *}(0.064)$ \\
\hline $\operatorname{InTR}$ & $0.213^{* *}(0.113)$ \\
\hline Constant & $1.667(0.004)$ \\
\hline Sargan test (p value) & 0.5643 \\
\hline AR1: $p$-value & 0.0000 \\
\hline AR2: $p$-value & 0.3342 \\
\hline
\end{tabular}

Notes: ${ }^{* * *},{ }^{* *}$ and ${ }^{*}$ denote significance at the $1 \%, 5 \%$ and $10 \%$ levels, respectively Between ( ) are the standard errors

Table 3: GMM dynamic estimation. 
Citation: Abdelbagi E (2016) Migration, Remittances, Trade Openness and Economic Growth in Africa: GMM Technique. J Glob Econ 4: 193. doi:10.4172/2375-4389.1000193

from 1976 to 2015. The study utilized annual data obtained from the World Bank and used GMM econometrics technique. The empirical results found that outgoing migration has negative significant impact on economic growth of the region, while migrants' remittances to Africa have positive significant impact on economic growth during period of interest. Also, trade contributes positively and significantly to economic growth in the continent. The study provided a better underpinning for African policy-maker to introduce effective polices that may enhance the trade environment to gain more positive impact on the growth of the economy. Also, to introduce polices that help African countries to limit the outgoing migration in order to keep skilled and trained labors in Africa. In addition, to introduce polices that develop the financial system to benefit more positive impact from the migrants' remittances on economic growth of the region.

\section{References}

1. Di Maria C, Emiliya L (2012) Migration, Human Capital Formation, and Growth An Empirical Investigation. World Development 40: 938-955.

2. Abdelbagi E, Azali M, Azman H, Norashidah MD (2015) The Impact of Government Spending, Trade, Foreign Aid and Foreign Direct Investment on Poverty Reduction in Africa: GMM Estimation. International Journal of Economics and Management Sciences 5: 1-6.

3. Ortega F, Giovanni P (2014) Openness and Income: The Roles of Trade and Migration. Journal of International Economics 92: 231-251.

4. Arndt C (2006) HIVIAIDS, Human Capital, and Economic Growth Prospects for Mozambique. Journal of Policy Modeling 28: 477-489.

5. Gyimah-Brempong K, Mark W (2004) Health Human Capital and Economic Growth in Sub-Saharan African and OECD Countries. The Quarterly Review of Economics and Finance 44: 296-320.

6. Abdelbagi E, Azali M, Azman H, Norashidah MD (2016) What Factors Determines the FDI Net Flows in Africa? GMM and PMG Techniques. Journal of Global Economics 4: 1-8.
7. Abdelbagi E (2015) Human Capital, Infrastructure and Economic Growth in Arab World: A Panel Granger Causality Analysis. Business and Economics Journal 7: $1-5$

8. Nyamongo EM, Roseline NM, Leonard K, Lydia N (2012) Remittances, Financial Development and Economic Growth in Africa. Journal of Economics and Business 64: 240-260

9. Diao X, Alejandro NP (2007) Growth Options and Poverty Reduction in Ethiopia-An Economy-Wide Model Analysis. Food Policy 32: 205-228.

10. Christiaensen L, Yasuyuki T (2014) Poverty Reduction during the Rural-Urban Transformation-The Role of the Missing Middle. World Development 63: 43-58.

11. Yanikkaya H (2003) Trade Openness and Economic Growth: A Cross-Country Empirical Investigation. Journal of Development Economics 72: 57-89.

12. Giuliano P, Marta RA (2009) Remittances, Financial Development, and Growth Journal of Development Economics 90: 144-152.

13. Combes JL, Christian E (2011) Remittances and Household Consumption Instability in Developing Countries. World Development 39: 1076-1089.

14. Gupta S, Catherine P, Smita W (2009) Effect of Remittances on Poverty and Financial Development in Sub-Saharan Africa. World Development 37: 104-115.

15. Le T (2011) Remittances for Economic Development: The Investment Perspective. Economic Modelling 28: 2409-2415.

16. Goschin Z (2014) Remittances as an Economic Development Factor. Empirica Evidence from the CEE Countries. Procedia Economics and Finance 10: 54-60.

17. Ziesemer, Thomas HW (2012) Worker Remittances, Migration, Accumulation and Growth in Poor Developing Countries: Survey and Analysis of Direct and Indirect Effects. Economic Modelling 29: 103-118.

18. Acosta P, Cesar C, Pablo F, Humberto L (2008) What Is the Impact of International Remittances on Poverty and Inequality in Latin America? World Development 36: 89-114.

19. Kroeger A, Kathryn HA (2014) Remittances and the Human Capital of Children New Evidence from Kyrgyzstan during Revolution and Financial Crisis, 20052009. Journal of Comparative Economics 42: 770-785.

20. Baltagi BH, Demetriades PO, Law SH (2009) Financial Development and Openness: Evidence from Panel Data. Journal of Development Economics 89: 285-296. 